\title{
Investigation of Leisure Time, Life and Sleep Quality in University Students
}

\author{
Nazan Ozturk ${ }^{1}$ and Fatma Unver ${ }^{2}$ \\ 1. Home Health Care Services Program, Department of Health Care Services, Soke Vocational School of Health Services, Aydin \\ Aydin Adnan Menderes University, Aydin 09010, Turkey \\ 2. School of Physical Therapy and Rehabilitation, Pamukkale University, Denizli 20070, Turkey
}

\begin{abstract}
Objective: This study aimed to determine the physical activity level of university students, to compare them according to gender and to investigate the effect of physical activity level on sleep and quality of life. Materials and Methods: The research is of an analytical-cross-sectional type. In total, 288 (181 F, $107 \mathrm{M})$ university students with a mean age of $19.59 \pm 2.00$ years participated in the study. Height, weight and waist circumference measurements were taken. Participants were asked a questionnaire to determine their socio-demographic characteristics and exercise, the Pittsburgh Sleep Quality Index (PSQI) for assessing sleep quality, Godin Leisure Time Exercise Questionnaire to measure 1-week total physical activity level and SF-36 (Brief) to assess the quality of life. Quality of Life Questionnaires were applied by face-to-face questionnaire method. Results: 39\% of the students were active, $18 \%$ were moderately active, and $43 \%$ were not active enough. When the data of girls and boys were compared, only the height, body weight, waist circumference, Body Mass Index (BMI) and Godin Leisure Time Exercise Questionnaire, SF 36 had a significant difference in emotional role difficulty results in favor of men $(p<0.00)$. Social functioning and general health perception $(r=0.116$; $r=0.119$ ) of the SF-36 quality of life questionnaire were found to be positively correlated with the energy/vitality component of Godin leisure time questionnaire and SF-36 quality of life questionnaire $(r=0.121)$. There was a low positive correlation between sleep quality and all components of the SF-36 quality of life questionnaire $(0.168<r<0.333)$. Conclusion: As a result, only $39 \%$ of university students are active and spend more time on computers and phones. Boys had a physically more active lifestyle than girls. In the young population, physical activity did not affect sleep quality, but sleep quality affected quality of life. For health and quality life, the participation of individuals in regular exercise should be encouraged, physical activity programs should be organized and motivated in universities.
\end{abstract}

Key words: Physical activity, quality of life, sleep quality.

\section{Introduction}

Physical activity is necessary for the protection of the health of individuals and quality of life. Today, with the development of technology, people's physical activities in daily life have decreased [1]. Physical activity is one of the primary risk factors for cardiovascular disease but may also play a role in the development of chronic diseases such as diabetes and rheumatic diseases. The number of people suffering from these diseases, which are defined as chronic diseases, is gradually increasing and this brings a great burden to societies in terms of material

Corresponding author: Fatma Unver, professor, research fields: exercise and health, sports injuries, sports science. and spiritual. Both treatment and care costs of chronic diseases constitute an important expense item in the health expenditures of countries [2]. These costs can not be fully met by developing societies, and individuals either die at an early age or are doomed to a lower quality of life. This is why it is important to prevent and treat chronic diseases. It is a known fact that preventing the occurrence of diseases is cheaper and easier than treatment. It has been observed that physical activity is an important element to prevent chronic diseases [3]. According to the World Health Organization (WHO), more than 2 million people die each year for not doing physical activity [4]. Physical activity is defined as activities that occur with energy consumption using muscles 
and joints in daily life, increase heart rate and respiratory rate and result in fatigue of different intensities [5].

Physical activity is defined as voluntary body movements produced by skeletal muscle. It includes activities such as hiking and stair climbing to shopping malls which are a part of daily life. Physical activity increases energy consumption [6]. Physical activity has positive effects such as reducing anxiety, stress, and depression and providing mental health and psychological vitality [7]. This is important for protection from diseases, including chronic diseases, especially for protection from depression [8].

Regular physical activity increases exercise capacity and physical fitness, which are known to have numerous health benefits. Accurate determination of physical activity and fitness is essential for the health benefits and effectiveness of intervention programs. Intensity, frequency, duration in physical activity all need to be measured and evaluated. Physical activity and exercise were associated with better sleep and less sleep disturbance in healthy adults. Poor sleep quality and abnormal sleep duration (more than or less than 7-8 hours per day) are associated with increased morbidity and mortality. Exercises performed more than one hour a day were found to be associated with longer sleep time; low-intensity exercise was found to have positive effects on sleep [9].

The activity level of young people is more difficult to measure than adults, because the activities of young people are more intermittent and shorter duration than adults [10].

The university period is the period in which an individual strives to become a young adult beyond his adolescence. Turkey constitutes a large group of college students that need to be considered in terms of health [11]. The years of higher education, the early years of late adolescence and adulthood are a period in which many lifestyle decisions are taken. This period is a time when health-conscious choices can be made instead of harmful behaviors to health when smart decisions are taken [12].

The questionnaire is a widely and practically used method to measure physical activity in epidemiological studies. Physical activity surveys are easy, inexpensive and applicable to a large population. At the end of physical activity surveys, activity levels of individuals can be estimated as low, medium and high, as well as calorie consumption or MET [13].

Different studies have been conducted on the determination of sleep quality and physical activity level in our country, but the relationship between these two parameters has not been fully clarified yet. Again, when the literature is examined, there are no studies to determine leisure activity, quality of life and sleep among university students.

Therefore, this study was planned to determine the effect of physical activity level on sleep and quality of life of university students.

\section{Method}

The population of the study consisted of the students of Aydın Adnan Menderes University Söke Vocational School of Health Services. The number of students to be sampled was determined as $\alpha=0.05$ with a 95\% confidence interval using a certain sampling method, and 235 with $p=5.0$. The study was carried out with the students who attended the Adnan Menderes University, Söke School of Health Services between November 15 and December 15, 2018, and accepted to participate in the study. Permission was obtained from the Non-interventional Ethics Committee of the Faculty of Health Sciences of Aydın Adnan Menderes University.

\section{Data Collection Tools}

\subsection{Demographic Information Form}

The form which was prepared by the researchers with the support of the literature contains questions including sociodemographic characteristics of the participants such as age, height, weight, educational status. 


\subsection{Pittsburgh Sleep Quality Index (PSQI)}

It was developed by Buysse et al. [14] in 1989 for the evaluation of sleep quality in psychiatric applications and clinical research. This index contains 19 items designed to evaluate sleep quality in the last month. It consists of subjective sleep quality, sleeps latency, sleep duration, habitual sleep activity, sleep disturbance, sleep medication use, and daytime sleep dysfunction. Each component is evaluated on a score of $0-3$. The total score has a value of $0-21$. A higher total score indicates poor sleep quality. A total PSQI score greater than 5 indicates an important level of sleep disorder. The validity and reliability studies of this scale for our country were conducted by Ağargün et al. in 1996 [15].

\subsection{Godin Leisure Time Exercise Questionnaire}

It is used to measure 1-week total physical activity level. It contains 3 questions about the frequency of mild, moderate and severe exercise performance. Higher scores indicate higher levels of physical activity [16].

\subsection{SF-36 (Short Form) Quality of Life Questionnaire}

This is a general health screening survey designed in the USA. It was shown to be valid and acceptable in the healthy population and reliability studies were performed in different patient groups [17]. SF-36 Quality of Life Scale is the most widely used generic scale. It is a valid and widely used criterion for assessing the quality of life. It is not specific to any age, disease or treatment group. It includes general health concepts, developed for use in clinical practice and research. The reliability and validity study of the Turkish version of SF-36 was conducted by Koçyiğit et al. [18]. The scale consists of 36 items and provides the measurement of 8 dimensions; physical function (10 items), social function (2 items), role limitations due to physical functions (4 items), role limitations due to emotional problems (3 items), mental health (5 items), energy/vitality (4 items), pain (2 items) and general perception of health (5 items) [17]. The evaluation is done with a Likert-type scale, except for some health items, and the condition of the patients in the last four weeks is taken into consideration. The subscales evaluate health between $0-100$, and the higher the score, the better the quality of life. It has been reported that it can be used to evaluate the quality of life in patients with physical illness [19, 20]. 0 indicates poor health, 100 indicates good health.

\section{Statistical Analysis}

SPSS 20.0 program was used for coding, transferring and analysis of data. Results are given as mean and standard deviation. The relationship between the results was compared with Pearson Correlation Analysis when parametric assumptions were provided and Spearman Correlation Analysis when non-parametric assumptions were provided.

\section{Results}

The physical characteristics of the participants ( $n=$ 235), sleep, sitting and time spent in front of the computer are shown in Table 1, leisure time, sleep and quality of life data are shown in Table 2.

Table 1 Body composition, sleep, sitting and computer time characteristics of the participants $(n=235)$.

\begin{tabular}{lll}
\hline Variables & Average & Standard deviation \\
\hline Age (years) & 19.57 & 2.00 \\
Body weight $(\mathrm{kg})$ & 61.60 & 10.87 \\
High $(\mathrm{cm})$ & 167.16 & 8.90 \\
Body mass index $\left(\mathrm{kg} / \mathrm{cm}^{2}\right)$ & 22.06 & 3.87 \\
Waist circumference (cm) & 73.98 & 10.75 \\
Time spent sitting in school (hour) & 3.13 & 1.69 \\
Daytime sleep time (hour) & 3.06 & 3.72 \\
When you sleep at night (hour) & 7.77 & 2.52 \\
Time spent on television (hour) & 1.02 & 1.56 \\
Time spent at the phone, computer (hour) & 4.29 & 3.48 \\
\hline
\end{tabular}


Table 2 Leisure time, sleep and quality of life data of the participants $(n=235)$.

\begin{tabular}{lll}
\hline Leisure time, sleep and quality of life variables & Average & Standard deviation \\
\hline Godin leisure time exercise questionnaire scores & 21.56 & 2.16 \\
SF-36 (short form) quality of life & 86.63 & 19.54 \\
SF36 physical role difficulty & 66.10 & 35.88 \\
SF36 emotional role difficulty & 48.10 & 41.17 \\
SF36 energy/vitality & 48.10 & 20.61 \\
SF36 mental health & 53.02 & 19.64 \\
SF36 social functionality & 67.17 & 23.32 \\
SF36 pain & 70.04 & 21.48 \\
SF36 general health perception & 58.72 & 17.62 \\
Pittsburgh sleep quality index & 7.31 & 3.44 \\
\hline
\end{tabular}

When the relationship between leisure time, sleep quality, quality of life, Body Mass Index (BMI) is examined (Table 3), social functioning and general health perception of BMI and SF-36 quality of life questionnaire are low level between energy and vitality component of Godin leisure time and SF-36 quality of life questionnaire. There was a positive relationship $(p<0.05)$. There was a low positive correlation between sleep quality and all components of the SF-36 quality of life questionnaire $(p<0.01)$. When the data of the girls and boys were compared, only the height, body weight, waist circumference, BMI and Godin Leisure Time Exercise Questionnaire, SF-36 were found to have a significant difference in emotional role difficulties in favor of men $(p=0.00)$ (Table 4).

\section{Discussion and Conclusion}

As a result of the study, only $39 \%$ of university students are active, spend more time on computers and phones; male participants had a physically more active lifestyle than female participants. In addition, it was seen that body mass index positively affected social functioning and general health perception of SF-36 quality of life questionnaire, the physical activity status of an energy-vitality component of SF-36 quality of life questionnaire. Sleep quality was found to have a low positive effect on all components of quality of life.

In the study, 39\% of the participants were active, $18 \%$ were moderately active and $43 \%$ were not active enough. When the data of girls and boys were compared, only significant differences were found in favor of males in height, body weight, weight, waist circumference, BMI and Godin Leisure Time Exercise Questionnaire and SF-36 emotional role difficulty parameter $(p=0.00)$. In parallel with the study, Mota and Esculcas [21] found similar results in their studies and stated that boys were more active than girls. Baş Aslan et al. [22], in order to determine the physical activity levels of university students with physical activity questionnaire and cardiorespiratory fitness measure and to evaluate the differences in physical activity habits according to gender, physical activity habits of students used Physical Activity Assessment (FAD) Questionnaire and cardiorespiratory endurance was one-mile walking test. As a result of the study, it is stated that the activity level of male students is higher than female students [22]. Pereiraa et al. [23] included 866 students in their study, which looked at the relationship between perceived environmental factors and leisure and physical activity. Perceptions of environmental factors were evaluated by the Physical Activity and Fitness Assessment Questionnaire (ALPHA). Participants were sedentary, low active; moderately active, and very active. Males were more involved in structured physical activity, frequency and intensity of physical activity than in girls in sports competitions [23].

Tekkanat [24] used the World Health Organization Quality of Life-Short Form (WHOQOL-BREF) to measure students' quality of life and the International 


\begin{tabular}{|c|c|c|c|c|c|c|c|c|c|c|c|c|c|c|c|c|c|}
\hline & 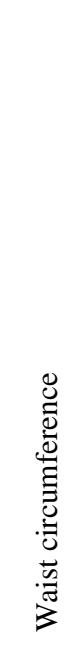 & 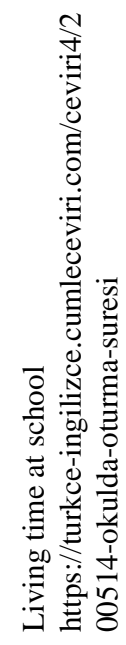 & 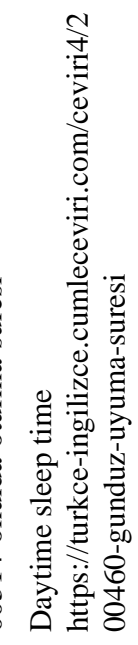 & 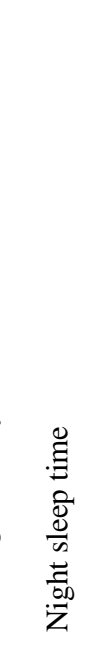 & 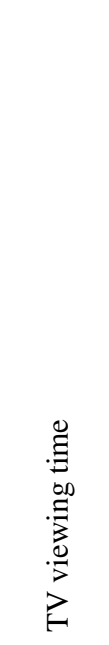 & 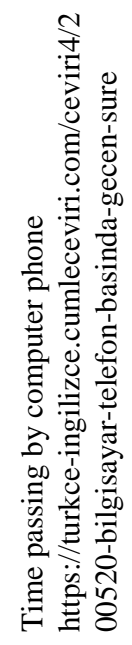 & $\sum_{\infty}^{F}$ & 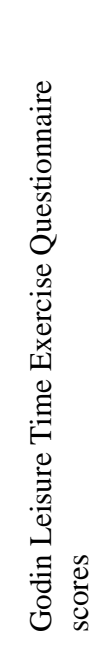 & 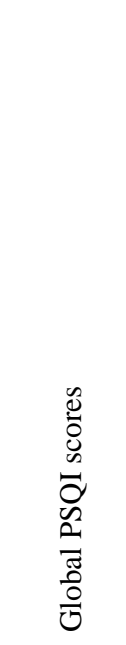 & 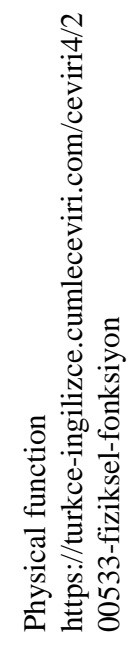 & 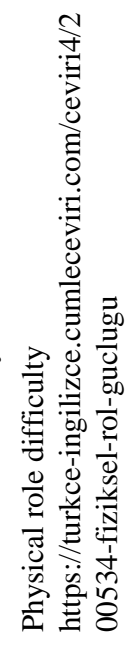 & 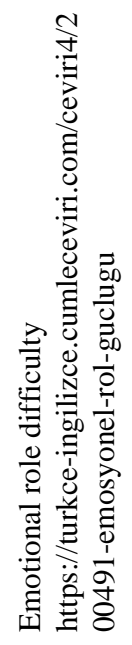 & 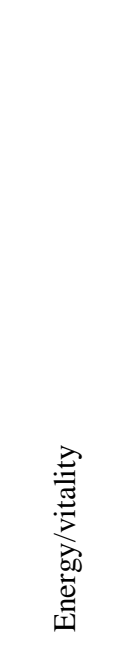 & 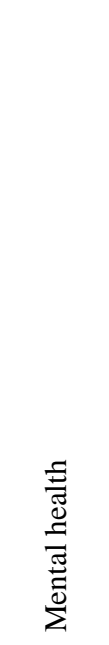 & 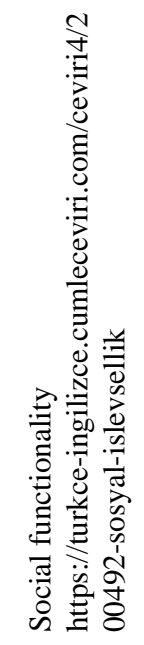 & ت & 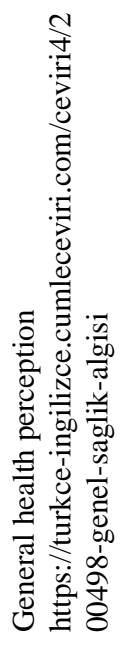 \\
\hline Waist circumference & 1 & 0.099 & 0.007 & -0.083 & 0.037 & -0.031 & $0.664^{* *}$ & $0.165^{*}$ & -0.015 & $0.204^{* *}$ & 0.040 & 0.061 & 0.016 & -0.003 & $0.144^{*}$ & 0.049 & $0.180^{* *}$ \\
\hline Living time at school & & 1 & 0.246 & 0.023 & 0.023 & $0.127^{*}$ & -0.048 & 0.062 & 0.012 & -0.022 & 0.031 & 0.097 & -0.007 & -0.029 & 0.006 & 0.038 & 0.097 \\
\hline Daytime sleep time & & & 1 & 0.220 & -0.088 & -0.119 & -0.052 & -0.024 & -0.072 & 0.113 & 0.048 & 0.135 & 0.193 & 0.101 & 0.051 & 0.075 & 0.223 \\
\hline Night sleep time & & & & 1 & -0.009 & $-0.157^{* *}$ & -0.003 & -0.058 & $-0.254^{* *}$ & -0.031 & 0.028 & 0.041 & -0.054 & -0.003 & -0.056 & -0.023 & 0.002 \\
\hline TV viewing time & & & & & 1 & 0.079 & 0.038 & 0.075 & 0.112 & -0.094 & -0.041 & 0.011 & -0.045 & -0.050 & -0.080 & -0.077 & -0.075 \\
\hline Time passing by computer & & & & & & 1 & -0.030 & 0.033 & 0.107 & 0.048 & 0.034 & 0.053 & -0.068 & -0.066 & 0.015 & 0.048 & 0.055 \\
\hline BMI & & & & & & & 1 & 0.046 & 0.006 & 0.015 & 0.001 & 0.059 & 0.003 & 0.023 & $0.116^{*}$ & 0.061 & $0.119^{*}$ \\
\hline $\begin{array}{l}\text { Godin Leisure Time } \\
\text { Exercise Questionnaire } \\
\text { scores }\end{array}$ & & & & & & & & & 0.041 & -0.003 & -0.028 & -0.056 & $-0.121^{*}$ & -0.072 & -0.066 & -0.088 & -0.012 \\
\hline Global PSQI scores & & & & & & & & & & $-0.168^{* *}$ & $-0.193^{* *}$ & $-0.211^{* *}$ & $-0.333^{* *}$ & -0.253 & $-0.250^{* *}$ & -0.277 & $-0.255^{* *}$ \\
\hline
\end{tabular}

$* p<0.05$

$* * p<0.01$. 
Table 4 Comparison of measurement data by gender.

\begin{tabular}{|c|c|c|c|c|c|}
\hline Variables & Gender & $N$ & Average & Standard deviation & $p$ \\
\hline \multirow{2}{*}{ Age } & Female & 181 & 19.44 & 1.82 & \multirow{2}{*}{0.185} \\
\hline & Male & 107 & 19.79 & 2.27 & \\
\hline \multirow{2}{*}{ Body weight } & Female & 181 & 56.49 & 8.21 & \multirow{2}{*}{$0.000^{*}$} \\
\hline & Male & 107 & 70,34 & 9.12 & \\
\hline \multirow{2}{*}{ High } & Female & 181 & 162.83 & 5.16 & \multirow{2}{*}{$0.000^{*}$} \\
\hline & Male & 107 & 174.48 & 9.13 & \\
\hline \multirow{2}{*}{ Waist circumference } & Female & 181 & 70.62 & 8.75 & \multirow[t]{2}{*}{$0.000 *$} \\
\hline & Male & 107 & 80.04 & 11.40 & \\
\hline \multirow{2}{*}{ Living time at school } & Female & 181 & 3.02 & 1.65 & \multirow{2}{*}{0.192} \\
\hline & Male & 107 & 3.31 & 1.75 & \\
\hline \multirow{2}{*}{ Sitting time outside school } & Female & 181 & 5.62 & 3.79 & \multirow{2}{*}{0.287} \\
\hline & Male & 107 & 6.20 & 4.65 & \\
\hline \multirow{2}{*}{ Daytime sleep time } & Female & 181 & 3.20 & 4.42 & \multirow{2}{*}{0.658} \\
\hline & Male & 107 & 2.76 & 1.51 & \\
\hline \multirow{2}{*}{ Night sleep time } & Female & 181 & 6.47 & 1.80 & \multirow{2}{*}{0.364} \\
\hline & Male & 107 & 6.24 & 2.22 & \\
\hline \multirow{2}{*}{ TV viewing time } & Female & 181 & 0,91 & 1.37 & \multirow{2}{*}{0.125} \\
\hline & Male & 107 & 1.20 & 1.83 & \\
\hline \multirow{2}{*}{ Time passing by computer } & Female & 181 & 4.27 & 3.32 & \multirow{2}{*}{0.449} \\
\hline & Male & 107 & 4.31 & 3.76 & \\
\hline \multirow{2}{*}{ BMI } & Female & 181 & 21.33 & 3.15 & \multirow{2}{*}{$0.000^{*}$} \\
\hline & Male & 107 & 23.29 & 4.61 & \\
\hline \multirow{2}{*}{ Godin LeisureExercise Questionnaire scores } & Female & 181 & 18.10 & 17.64 & \multirow{2}{*}{$0.000 *$} \\
\hline & Male & 107 & 27.45 & 27.34 & \\
\hline \multirow{2}{*}{ Global PSQI scores } & Female & 181 & 7.28 & 3.42 & 0858 \\
\hline & Male & 107 & 7.36 & 3.48 & 0.030 \\
\hline Pbucical function & Female & 181 & 86.43 & 18.53 & 0833 \\
\hline Filysical iumctionte & Male & 107 & 86.96 & 21.23 & 0.025 \\
\hline Phycical role difficults & Female & 181 & 67.45 & 35.67 & 0763 \\
\hline 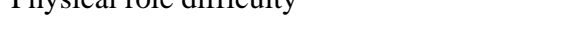 & Male & 107 & 66.12 & 36.38 & 0.703 \\
\hline Fmotional role difficulty & Female & 181 & 44.14 & 41,15 & $0023 *$ \\
\hline Emotronal rore anmcunty & Male & 107 & 54.83 & 40.50 & 0.035 \\
\hline Eneroy/vitality & Female & 181 & 47.45 & 20.45 & 0484 \\
\hline Eileigy/vildilly & Male & 107 & 49.21 & 20.94 & 0.404 \\
\hline Mental health & Female & 181 & 53.12 & 19.81 & 0.926 \\
\hline ivientar neditul & Male & 107 & 52.90 & 19.43 & 0.520 \\
\hline Social functionality & Female & 181 & 65.93 & 23.40 & 024 \\
\hline social runctionallty & Male & 107 & 69.28 & 23.12 & 0.24 \\
\hline Doin & Female & 181 & 70.21 & 20.64 & 0.957 \\
\hline Pam & Male & 107 & 69.77 & 22.93 & 0.037 \\
\hline feneral health nercention & Female & 181 & 57.45 & 17.90 & 0109 \\
\hline General neanm percepuon & Male & 107 & 60.89 & 17.00 & 0.109 \\
\hline
\end{tabular}

$* p<0.05$. 
Physical Activity Inventory (IPAQ) to measure physical activity levels. A positive relationship was found between quality of life and physical activity in all students, and it was reported that quality of life differed significantly in favor of men. In the study conducted by Pedišić et al. [25] on physical activity and quality of life among university students, leisure time was found to be positively correlated with quality of life $(r=0.8)$. As a result of multiple linear regression analysis, it was found that physical activity was associated with Physical Summary Component score ( $\beta=0.08$ for women and $\beta=0.10$ for women, $p$ $<0.05$ ) only in their spare time. Peleias et al. [26] stated that $40 \%$ of medical students did not do physical activity in their free time as a result of another study. They found that the quality of life of those doing moderate and high activity was better. They reported a similar effect between leisure-time physical activity and quality of life in girls and boys. In our study, when the data of girls and boys were compared, a significant difference was found in favor of men in terms of height, body weight, waist circumference, BMI and Godin Leisure Time Exercise Questionnaire, and SF-36's emotional role difficulty results. Boys live a more active life than girls and this affects the emotional role difficulty of quality of life. The difference in physical properties is the expected natural results.

In our study, the time spent at the beginning of television was $0.99 \pm 1.53 \mathrm{~h}$, the time spent at the beginning of the computer and telephone was $4.28 \pm$ 3.49 , week-time sleep time was $6.47 \pm 1.85$, and weekend time was $7.80 \pm 2.42$ hours. Physical activity status, quality of life except for energy/vitality component and sleep quality did not affect. This may be due to the fact that our sample group generally has a low level of physical activity. We think that different results may be obtained in different populations whose physical activity group is more heterogeneous.

Wang et al. [27] looked at the relationship between students' sleep quality and behavior and evaluated sleep quality with the Pittsburgh Sleep Quality Scale. As a result of the study, sleep quality was found to be poor in those who exercise less than three times a week. In contrast to this study, the results of our study showed that the physical activity level of university students had no effect on sleep quality.

As a result, it was seen that the majority of healthy young university students were physically inactive, the time spent on the phone and computer exceeded one-sixth day, physical activity did not affect sleep quality for this population, and sleep quality had a positive effect on the quality of life. It is recommended that physical activity programs should be organized and motivated to participate in the university in order to examine the nutritional habits in future studies for healthy life and aging.

\section{References}

[1] Eyre, H. A., Papps, E., and Baune, B. T. 2013. "Treating Depression and Depression-Like Behavior with Physical Activity: An Immune Perspective.” Review Artıcle. doi: 10.3389/fpsyt.2013.00003.

[2] De Vreede, P. L., Samson, M. M., Van Meeteren, N. L., Van Der Bom, J. G., Duursma, S. A., and Verhaar, H. J. 2004. "Functional Tasks Exercise versus Resistance Exercise to Improve Daily Function in Older Women: A Feasibility Study.” Arch Phys Med Rehabil 85: 1952-61.

[3] Veenhof, C., Köke, A. J., Dekker, J., Oostendorp, R. A., Bijlsma, J. W., Van Tulder, M. W., et al. 2006. "Effectiveness of Behavioral Graded Activity in Patients with Osteoarthritis of the Hip and/or Knee: A Randomized Clinical Trial.” Arthritis Rheum 55: 925-34.

[4] Pal, S., Cheng, C., Egger, G., Bınns, C., and Donovan, R. 2009. "Using Pedometers to Increase Physical Activity in Overweight and Obese Women: A Pilot Study." BMC Public Health 9: 309.

[5] Bek, N. 2008. Fiziksel Aktivite ve Sağlı̆̆ımız, Fiziksel Aktivite Bilgi Serisi. Edited by Irmak, H., Kesici, C., Çakır, B., Akıncı, N., and Beşer, Z. Ankara: Sağlık Bakanlığı Yayın.

[6] Taraldsen, K., Chastin, S. F., Riphagen, I. I., Vereijken, B., and Helbostad, J. L. 2012. "Physical Activity Monitoring by Use of Accelerometer-Based Body-Worn Sensors in Older Adults: A Systematic Literature Review of Current Knowledge and Applications.” Maturitas 71: 13-9.

[7] Nelson, M. E., Rejeski, W. J., Blair, S. N., Duncan, P. W., Judge, J. O., and King, A. C. 2007. "Physical Activity 
and Public Health in Older Adults: Recommendation from the American College of Sports Medicine and the American Heart Association.” Circulation 116: 1094-8.

[8] Washburn, R. A., Smith, K. W., Jette, A. M., and Janney, C. A. 1993. "The Physical Activity Scale for the Elderly (PASE): Development and Evaluation.” Journal of Clinical Epidemiology 46: 153-62.

[9] Borodulin, K., Evenson, K. R., Monda, K., et al. 2010. "Physical Activity and Sleep among Pregnant Women." Pediatr Perinat Epidemiol 24: 45-52.

[10] Baltacı, G., Düzgün, İ., and Ve Egzersiz, A. 2008. Să̆lık Bakanlı̆̆ Yayınları. Ankara: Birinci Basım.

[11] Karabulutlu, Ö., and Kılıç, M. 2011. "Üniversite öğrencilerinin cinsel sağlık üreme sağlık hakkındaki bilgi düzeylerinin belirlenmesi.” Anadolu Hemşirelik ve Sağlık Bilimleri Dergisi 2: 39-45.

[12] Doğan, T. 2004. "Üniversite öğrencilerinin iyilik halinin incelenmesi.” Doktora Tezi, Hacettepe Üniversitesi.

[13] Soyuer, F., and Soyuer, A. 2008. "Yaşl1lık ve fiziksel aktivite.” İn̈nü Üniversitesi Tıp Fakültesi Dergisi 15 (3): 219-24.

[14] Buysse, D. J., Reynolds, C. F., Monk, T. H., Berman, S. R., and Kupfer, D. J. 1989. “The Pittsburgh Sleep Quality Index: A New Instrument for Psychiatric Practice and Research.” Psychiatry Research 28 (2): 193-213.

[15] Ağargün, M. Y., Kara, H., and Anlar, Ö. 1996. "Pittsburgh uyku kalitesi indeksi'nin geçerliliği ve güvenirliliği.” Türk Psikiyatri Dergisi 7 (2): 107-15.

[16] Godin, G., and Shephard, R. J. 1985. "A Simple Method to Assess Exercise Behavior in the Community." Canadian Journal of Applied Sport Sciences 10 (3): 141-6.

[17] Ware, J. E., and Sherbourne, C. D. 1992. "The MOS 36-Item Short-Form Health Status Survey (SF-36). 1. Conceptual Framework and Item Selection.” Med Care 30 (6): 473-83.

[18] Koçyiğit, H., Aydemir, Ö., and Fisek, G. V. A. 1990. "Kısa Form-36'nın Türkçe Versiyonunun Güvenilirliği ve Geçerliliği.” İlaç ve Tedavi Dergisi.

[19] Heuker, D., Lengele, B., Delecluse, V., Weynand, B.,
Liistro, G., Balduyck, B., et al. 2011. "Subjective and Objective Assessment of Quality of Life after Chest Wall Resection.” Eur J Cardiothorac Surg. 39: 102-8.

[20] Tanriverdi, N., Ozçürümez, G., Colak, T., Dürü, C., Emiroğlu, R., Zileli, L., et al. 2004. "Quality of Life and Mood in Renal Transplantation Recipients, Donors, and Controls: Preliminary Report." Transplant Proc. 36: 117-9.

[21] Mota, J., and Esculcas, C. 2002. "Leisure-Time Physical Activity Behavior: Structured and Unstructured Choices according to Sex, Age, and Level of Physical Activity.” Int. J. Behav. Med 9: 111-21.

[22] Baş Aslan, U., Livanelioğlu, A., and Aslan, Ş. 2007. "Fiziksel aktivite düzeyinin üniversite öğrencilerinde iki farklı yöntemle değerlendirilmesi.” Fizyoter Rehabil 18 (1): 11-9.

[23] Pereira, R., Santos, R., Póvoas, S., and Silva, P. 2018. "Environment Perception and Leisure-Time Physical Activity in Portuguese High School Students.” Preventive Medicine Reports 10: 221-6.

[24] Tekkanat, Ç. 2008. “Öğretmenlik Bölümünde Okuyan Öğrencilerde Yaşam Kalitesi Ve Fiziksel Aktivite Düzeyleri.” Yüksek Lisans Tezi, Pamukkale Üniversitesi Sağlık Bilimleri Enstitüsü.

[25] Pedišić, Z., Rakovac, M., Titze, S., Jurakić, D., and Oja, P. 2014. "Domain-Specific Physical Activity and Health-Related Quality of Life in University Students." Eur J Sport Sci. 14 (5): 492-9. doi: 10.1080/17461391.2013.844861.

[26] Peleias, M., Tempski, P., Paro, H., Perotta, B., Mayer, F. B., Enns, S. C., Gannam, S., Pereira, M. A. D., Silveira, P. S., Santos, I. S., Carvalho, C. R., and Martins, M. A. 2017. "Leisure Time Physical Activity and Quality of Life in Medical Students: Results from a Multicentre Study.” BMJ Open Sport Exerc Med. 3 (1): e000213.

[27] Wang, L., Qin, P., Zhao, Y., Duan, S., Zhang, Q., Liu, Y., Hu, Y., and Sun, J. 2016. "Prevalence and Risk Factors of Poor Sleep Quality among Inner Mongolia Medical University Students: A Cross-Sectional Survey.” Psychiatry Res. 244: 243-8. 